\title{
Genome size of chrysophytes varies with cell size and nutritional mode
}

\author{
Jana L. Olefeld ${ }^{1} \cdot$ Stephan Majda ${ }^{1} \cdot$ Dirk C. Albach $^{2} \cdot$ Sabina Marks $^{1} \cdot$ Jens Boenigk $^{1}$ \\ Received: 12 October 2017 / Accepted: 22 April 2018 / Published online: 9 May 2018 \\ (C) The Author(s) 2018
}

\begin{abstract}
The cellular content of nuclear DNA varies up to 200,000-fold between eukaryotes. These differences can arise via different mechanisms. In particular, cell size and nutritional mode may influence evolution of the nuclear DNA content. Chrysophytes comprise organisms with different cell organizations and nutritional modes. Heterotrophic clades evolved independently several times from phototrophic or mixotrophic ancestors. Thus, chrysophytes are an ideal model taxon for investigating the effect of the nutritional mode on cellular DNA content. We investigated the genome size of heterotrophic, mixotrophic, and phototrophic chrysophytes. We demonstrate that cell sizes and genome sizes differ significantly between taxa with different nutritional modes. Phototrophic strains tend to have larger cell volumes and larger genomes than heterotrophic strains do. The investigated mixotrophic strains had intermediate cell volumes and small to intermediate genome sizes. Heterotrophic chrysophytes had the smallest genomes and cell volumes compared to other chrysophytes. In general, genome size increased with cell volume, but cell volume only partially explained the variation in genome size. In particular, genome sizes of mixotrophic strains were smaller than expected based on cell sizes.
\end{abstract}

Keywords Genome evolution $\cdot$ C-value $\cdot$ Heterotrophic nanoflagellates $\cdot$ Algae $\cdot$ Microbial eukaryotes $\cdot$ Stramenopiles

\section{Introduction}

The evolution of genome sizes is of special interest because huge variation in the amount of DNA (up to 200,000-fold for eukaryotes) are the result of complex interactions between various evolutionary forces (Kapraun 2005; Cavalier-Smith 2005; Gupta et al. 2016). Studies on the amount of nuclear DNA and on genome size (C-value) can have practical as well as predictive uses, as these parameters are important traits of a species (Bennett and Leitch 2005). Often, the amount of nuclear DNA is much higher than necessary for coding or regulatory sequences, a fact which is known as the $\mathrm{C}$-value paradox (Dolezel et al. 1998; Gupta et al. 2016). However, genome size

Electronic supplementary material The online version of this article (https://doi.org/10.1007/s13127-018-0365-7) contains supplementary material, which is available to authorized users.

Jana L. Olefeld

jana.olefeld@uni-due.de

1 Department of Biodiversity, University of Duisburg-Essen, Universitätsstraße 5, 45141 Essen, Germany

2 Department of Biodiversity and Evolution of Plants, Carl von Ossietzky University Oldenburg, Carl-von-Ossietzky-Straße 9-11, 26129 Oldenburg, Germany is generally correlated with cell volume (Dolezel et al. 1998); the widespread view that genome size will increase with the complexity of an organism seems therefore to hold only in the general sense that most eukaryotes have more DNA than prokaryotes or viruses (Cavalier-Smith 1982). Genome size is furthermore important for our understanding of its effect on phenotypic traits (nucleotype) in response to different environmental conditions (Kapraun 2005; Cavalier-Smith 1978; Dolezel et al. 1998).

During the life cycle of a species, changes in the genome size of certain cells (referring to gamets sensu lato) are possible, which is especially important if dealing with single-celled organisms. Haploid vegetative cells (e.g., in dinophytes) as well as diploid vegetative cells (e.g., in diatoms) are known. In general, asexual reproduction occurs, but also sexual reproduction (e.g., by producing haploid eggs and sperms or fusion of haploid vegetative cells) can be triggered (Koester et al. 2007; Kremp 2013).

Protists are particularly suited for studying mechanisms of genome size evolution in eukaryotes, because they are unicellular organisms which respond quickly to environmental changes. Further, the number of cell types (even in colonial species) is limited, and we face many different kinds of life cycles which have mostly evolved independently several times in phyla with different modes of nutrition and different 
cell structures (Cavalier-Smith 1980). Since some of the unicellular protists have considerably larger genomes than multicellular eukaryotes, studying single-celled protists allows the investigation of the full range of eukaryote $\mathrm{C}$-values (Cavalier-Smith 1982).

Here, we focus on the chrysophytes, which group in the Ochrophyta (Stramenopiles). They comprise a range of organisms with different life cycle stadia (e.g., silicate cysts or flagellated cells), cell organizations (e.g., colonial, branched, or single-celled morphologies), and nutrition modes such as phototrophy, heterotrophy, and mixotrophy (Boenigk et al. 2006). The Synurales are considered to be phototrophic (Kristiansen and Škaloud 2017) even though it is uncertain whether they can occasionally take up particles. However, as particulate food uptake is uncertain in the Sunyrales and of minor importance anyway, the Synurales are considerd to be phototrophic in the context of this study.

Heterotrophic chrysophytes evolved through parallel evolution several times independently within the Chrysophyceae (Grossmann et al. 2016). The plastids of these heterotrophic chrysophytes are in different stages of reduction and may be involved in several metabolic pathways as well as contain numerous photopigments (Graupner et al. 2018). However, the heterotrophic chrysophytes have in common the loss of chlorophyll and photosynthetic pathways as it had been demonstrated for several lineages so far (Graupner et al. 2018). They rely on particulate food uptake and prey on bacteria and other bacteria-sized microorganisms to gain carbon (Boenigk et al. 2005). Most chrysophyte species are mixotrophic, i.e., capable of photosynthesis and phagotrophy. In mixotrophs, particle uptake may be an additional source of nutrient uptake as, for instance, in nutrient-poor waters, or be the major route of carbon uptake. All different gradations from primarily phototrophic to primarily heterotrophic are realized in mixotrophic chrysophytes (Bock et al. submitted 2018).

Due to this diverse nutritional strategies, chrysophytes are important primary producers but also among the dominant bacterivores (Boenigk et al. 2005; Bock et al. 2014; Grossmann et al. 2016; Bock et al. submitted 2018).

Since chrysophytes are abundant in most temperate, freshwater habitats and occupy different niches, they play an important role in the regulation of microbial food webs (Bock et al. 2014).

Sexual reproduction occurs but is believed to be rare in chrysophytes. The dominant form of chrysophytes is a, probably haploid, vegetative swarmer, which can generally reproduce asexually, undergo encystment, or fuse to form a zygote. It has been suggested that sexuality can be induced, e.g., at high cell densities (e.g., in Synura) or by cyst formation (e.g., in Dinobryon) (Sandgren 1991; Kristiansen und Škaloud 2017).

In our study, we want to investigate the relationship between different nutrition modes and genome size in different chrysophyte strains with respect to their predominant nutrition mode. The basis of the genome size measurement is the correlation between DNA content and fluorescent staining. Linear regression of reference genome peaks enables calculation of an unknown sample DNA content. This has been shown highly reproducible for certain staining methods (Dolezel et al. 1998). Further, numerous authors stated and proved a correlation of cell volume and genome size (e.g., Bennett 1972). Additionally, heterotrophic chrysophytes are generally smaller than phototrophic ones, since they do only host remnants of a plastid (Škaloud et al. 2014; Grossmann et al. 2016; Graupner et al. 2018). Following these, we hypothesize phototrophic taxa to have larger genomes than heterotrophic ones, due to the differences in cell sizes. We further hypothesize that mixotrophic strains have a genome size intermediate between the other two groups, depending on the degree of phagocytosis and photosynthesis.

\section{Methods}

Chrysophyte cultures were obtained from the culture collection at University Duisburg-Essen and originate from sampling sites distributed worldwide (Table 1). They comprise various chrysophytes belonging to different orders and genera. Phototrophic chrysophyte strains are assigned to the Synurales and comprise the genera Mallomonas and Synura. Mixotrophic strains (mostly affiliated with the genera Dinobryon) are assigned to the Ochromonadales, as are most of the investigated heterotrophic chrysophyte strains. The investigated heterotrophic chrysophyte strains comprise representatives of various genera, e.g., Spumella, Pedospumella, or Segregatospumella (Findenig et al. 2010; Grossmann et al. 2016).

Further, this study will evaluate $1 \mathrm{C}$-values, referring to the overall DNA content of a haploid nucleus of a cell, which is usually constant in any species (Greilhuber et al. 2005). This ensures that differences, caused by the ploidy level, are evaded, even if we could not observe any sexual reproduction in our cultures, during the measurements. Therefore, the terms "genome size" and "C-value" have the same meaning.

\section{Culture conditions}

Cultures were grown in different media (IB (Hahn et al. 2003), NSY (Hahn et al. 2003), DY-V (Keller and Andersen, unpublished), or WC (Guillard and Lorenzen 1972)) depending on their growth requirements (Table $\mathrm{S} 1$ ) under a light/dark cycle of $12: 12 \mathrm{~h}$ at $16^{\circ} \mathrm{C}$. Culture flasks were only opened under sterile conditions. Phototrophic strains were grown in $500 \mathrm{~mL}$ TC-flasks, heterotrophic strains in 30-mL TC-flasks with bacteria supplied (Limnohabitans planktonicus; strain IID5 $5^{\mathrm{T}}$ ). Bacteria cultures were raised on $3 \mathrm{~g} \mathrm{~L}^{-1} \mathrm{NSY}$ medium and 


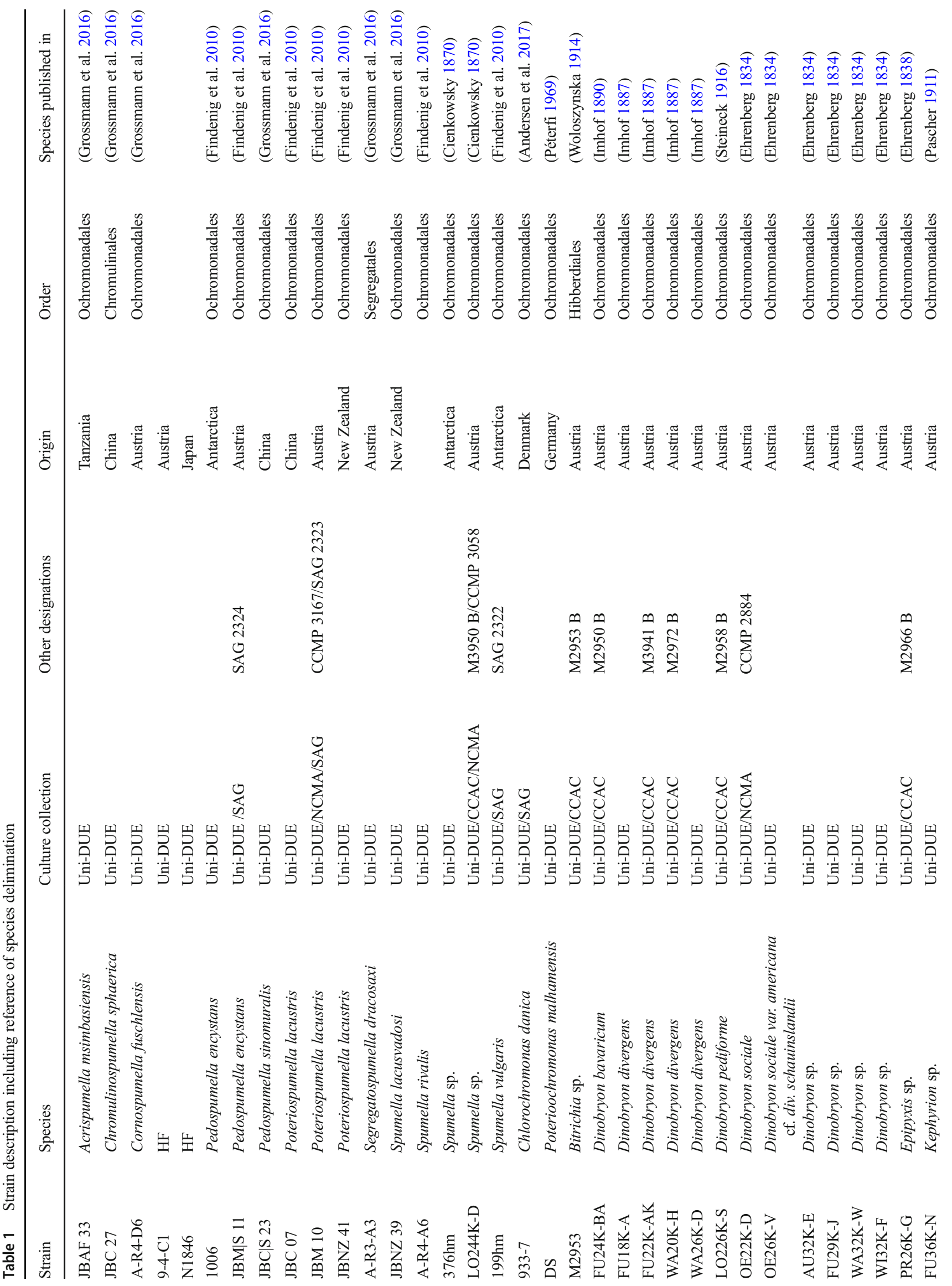




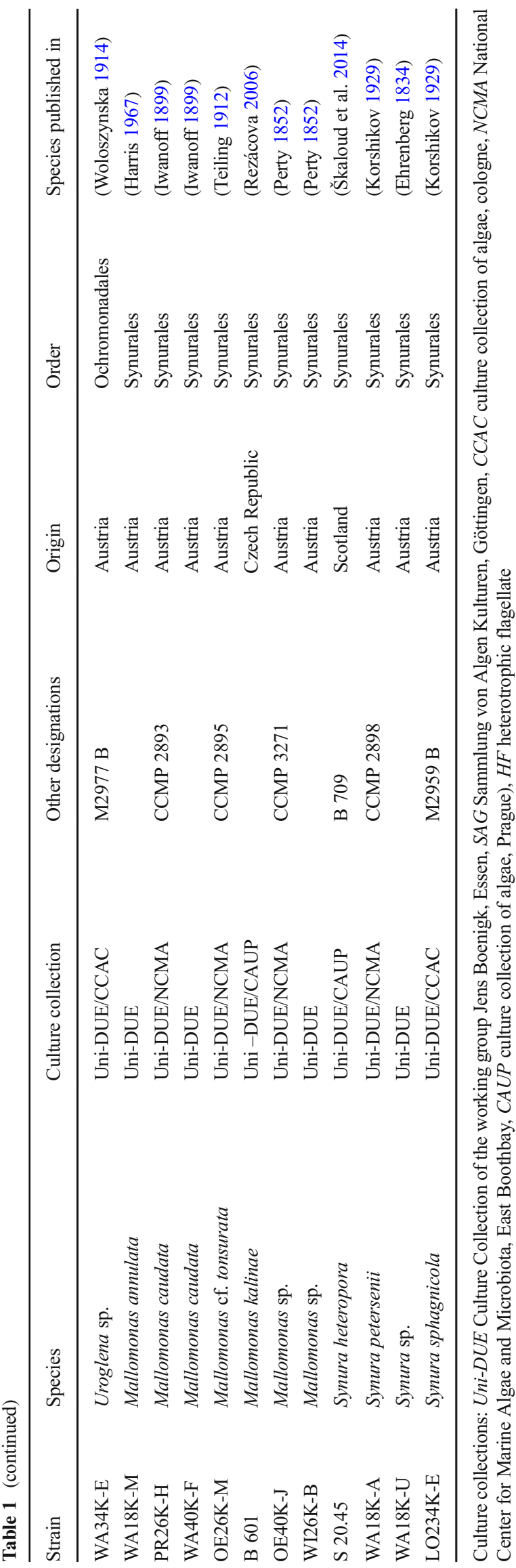

transferred to the correspondent chrysophyte culture medium. The chrysophyte strains Ochromonas danica (strain SAG9337), Poterioochromonas malhamensis (strain DS), and Poteriospumella laucustris (strains JBC07, JBM10, and JBNZ41) were grown axenically in $3 \mathrm{~g} \mathrm{~L}^{-1}$ NSY medium. The cultures were regularly checked using light microscopy.

\section{Sample preparation}

Nuclei extraction for plant reference standards (Table 2) was performed separately from chrysophyte samples as according to Galbraith et al. (1983) and Albach and Greilhuber (2004), using OTTO-1 isolation buffer and fresh plant leaf tissue: a piece of plant leaf $\left(1 \mathrm{~cm}^{2}\right)$ was placed into a Petri dish and covered with $550 \mu \mathrm{L}$ OTTO-1 isolation buffer. The leaf piece was chopped with a sharp razor blade. Afterwards, the resulting suspension was filtered through a $30 \mu \mathrm{m}$ nylon mesh (Partec $\left.{ }^{\circledR}\right)$. Afterwards, $50 \mu \mathrm{L}$ of RNAse-A solution $\left(3 \mathrm{~g} \mathrm{~L}^{-1}\right)$ was added, and the suspension was incubated in a preheated water bath at $37^{\circ} \mathrm{C}$ for $30 \mathrm{~min}$.

For chrysophyte sample preparation, we used cultures with a cell density of $1-3 \times 10^{5}$ cells $\mathrm{mL}^{-1}$. Samples were centrifuged to separate the cells from the medium (about 12,000 rpm; 2$4 \mathrm{~min})$. The pellets were diluted in $450 \mu \mathrm{L}$ OTTO- 1 isolation buffer and incubated at $50{ }^{\circ} \mathrm{C}$ for $5-10 \mathrm{~min}$ to achieve cell breakdown and make the nucleus accessible. Afterwards, $50 \mu \mathrm{L}$ of RNAse-A solution was added to the chrysophyte sample, and the cell suspension was incubated for $30 \mathrm{~min}$ at room temperature.

In cases, in which the chrysophyte Synura sphagnicola (strain LO234K-E) was used as standard for the measurement, both chrysophyte cultures were also prepared separately.

After RNAse incubation, the chrysophyte sample suspension was added to the reference standard suspension and mixed gently. This mixture of $450 \mu \mathrm{L}$ was stained with $2 \mathrm{~mL}$ of propidium iodide (PI) (Dolezel et al. 1992) and incubated at $4{ }^{\circ} \mathrm{C}$ for $60 \mathrm{~min}$.

Genome sizes were measured in four replicates containing a sample and the standard. The fluorescence of stained nuclei was quantified using a CyFlowSL flow cytometer (Partec GmbH, Münster, Germany) with excitation by a Green NdYAG laser tuned at $532 \mathrm{~nm}$. Genome size was estimated as according to Dolezel et al. (1992). The conversion of mass values into base-pair numbers was achieved using the factor $1 \mathrm{pg}=978 \mathrm{Mbp}$ (Dolezel et al. 2003).

Cell sizes of the chosen chrysophytes (living samples) were measured using a Nikon Eclipse Ti-S inverted microscope with $40 \times$ magnification. Cell length and width were obtained using the "NIS-Elements Basic Research" software. The cell volume was calculated using the formula for calculation of ellipsoid volumes. Average values were calculated from at least 35 cells. 
Table 2 Reference genome sizes of all used standards for flow cytometry

\begin{tabular}{llll}
\hline Standard & 1C value (reference GS) & Order & Published in \\
\hline Raphanus sativus & $0.55 \mathrm{pg}$ & Brassicales & (Doležel et al. 1998) \\
Solanum pseudocapsicum & $1.29 \mathrm{pg}$ & Solanales & (Temsch et al. 2010) \\
Hedychium gardnerianum & $2.01 \mathrm{pg}$ & Zingiberales & (Meudt et al. 2015) \\
Synura spagnicola (strain LO234K-E) & $0.20 \mathrm{pg}$ & Synurales & Newly established \\
\hline
\end{tabular}

\section{Statistical analyses}

Statistical analyses were performed using the program SigmaPlot 12.5 (Systat Software GmbH, Erkrath, Germany) and the software R (®The R Foundation). To evaluate if there were significant differences in genome sizes or cell sizes of phototrophic, heterotrophic, and mixotrophic chrysophyte strains, we used Kruskal-Wallis one-way ANOVAs on ranks (Kruskal and Wallis 1952), as the data did not show a normal distribution (Shapiro and Wilk 1965). ANOVAs were followed by Dunn's pairwise multiple comparison procedure (Dunn 1964). The family-wise error rate (FWER) was corrected using Šidák’s adjustment (Šidák 1967). We determined the relationship between genome size and cell size within one nutrition mode, as well as between all chrysophyte strains, using Bayesian regression models, determining the Bayesian $R_{s}^{2}$ following the solution of Gelman et al. (2017).

\section{Results}

Average cell volumes of investigated strains ranged between $111.85 \pm 65.67 \mu^{3}$ (strain $\mathrm{N} 1846$ ) and $8356.78 \pm$
$2961.43 \mu^{3}$ (strain WA40K-F; M.caudata) (Fig. 1). The interspecific variation of cell size was huge over all examined strains. M. caudata (strain WA40K-F) had a cell volume about 10 times higher than any other examined chrysophyte strain. Within one strain, cell volume variation increased with increasing cell volume. We detected significant differences between cell volumes of heterotrophic and phototrophic strains $(p=0.0002)$. The cell volume of mixotrophic strains was intermediate, significantly differing from phototrophic cell volumes $(p=0.0437)$ but not from heterotrophic cell volumes $(p=$ 0.0902).

Our genome size measurements demonstrate that chrysophytes cover a wide range of eukaryotic genome sizes, ranging from $0.045 \pm 0.001 \mathrm{pg}(44.2 \mathrm{Mbp}$; strain 9-4-C1) to $12.426 \pm 0.191 \mathrm{pg}(12,177.4 \mathrm{Mbp}$; strain WA40K-F; M. caudata) (Fig. 2). Mean genome sizes of heterotrophic chrysophytes $\left(\tilde{\mathrm{X}}^{\mathrm{H}}=0.077\right)$ varied significantly from mean genome sizes of phototrophic chrysophytes $\left(\tilde{\mathrm{x}}^{\mathrm{P}}=0.837 ; p \leq\right.$ 0.0001 ), as well as from mean genome sizes of mixotrophic chrysophytes $\left(\tilde{\mathrm{x}}^{\mathrm{M}}=0.154 ; p=0.0060\right)$. The difference between mean genome sizes of phototrophic and mixotrophic chrysophytes also varied significantly $(p=0.0015)$. Standard deviation was comparable small within one strain, among all

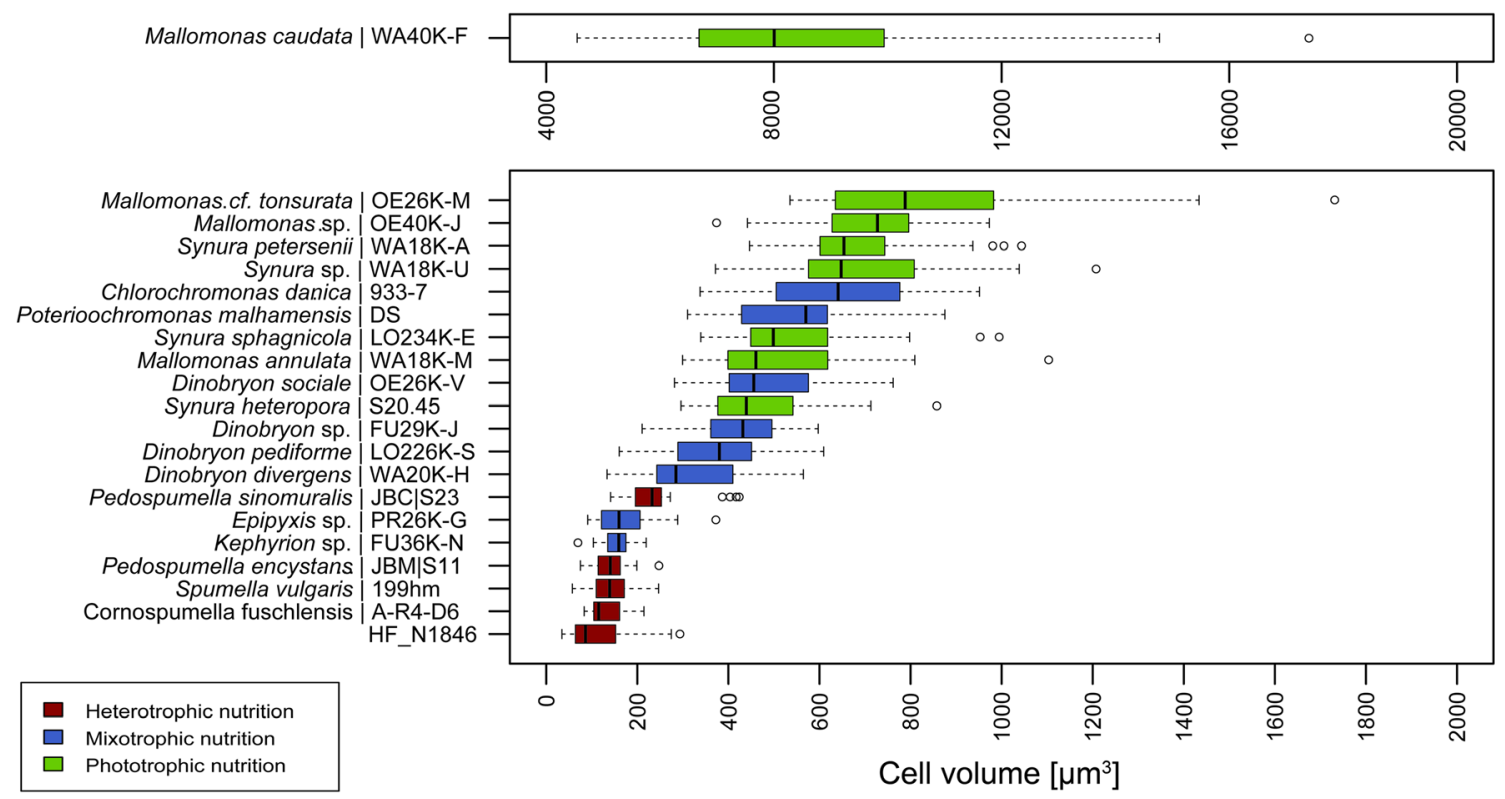

Fig. 1 Cell volumes $\left[\mu^{3}{ }^{3}\right]$ of different chrysophytes. Different colors represent the different nutritional modes present. Phototrophic chrysophytes (light green) do have highest cell volumes compared to heterotrophic (dark red) and mixotrophic (blue) chrysophytes. Heterotrophic chrysophytes had the smallest cell volumes. HF = Heterotrophic flagellate 
stains great variations occurred, especially between heterotrophic and phototrophic chrysophytes (Table S1).

Our results confirm that genome size generally increases with cell size in chrysophytes $\left(R_{s}^{2}=0.992\right)$. However, within the different trophic modes, this trend could only be confirmed for phototrophic $\left(R_{s}^{2}=0.997\right)$ and weakly for heterotrophic strains $\left(R_{s}^{2}=0.557\right)$ (Fig. 3). By contrast, for the investigated mixotrophic strains, genome size did not increase with cell size $\left(R_{s}^{2}=0.077\right)$. Nevertheless, results of partial correlations should be interpreted with caution since they are based on a small number of samples.

\section{Discussion}

Our study reveals differences in genome size and cell volume regarding the different nutritional modes observable in chrysophytes. Genome sizes of the investigated chrysophytes were generally within the range of reported genome sizes for eukaryotes (Fig. 4). In particular, the genome sizes of

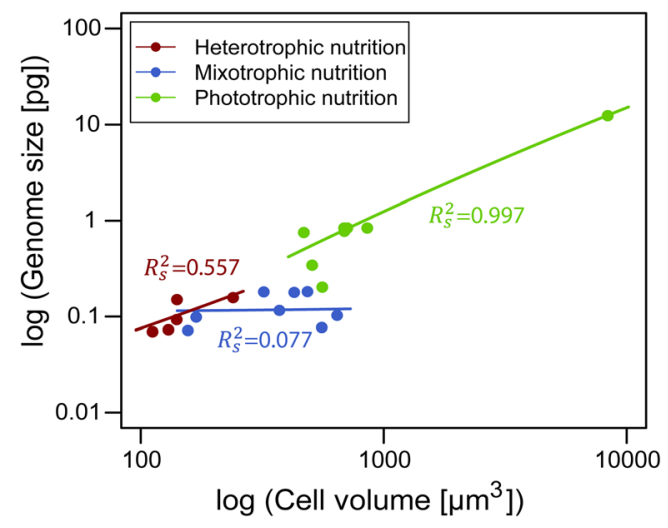

Fig. 3 Regression analysis of $\log$ (genome size [pg]) and log (cell volume $\left.\left[\mathrm{um}^{3}\right]\right)$. Different colors represent the different nutritional modes present (light green = phototrophic; drak red $=$ heterotrophic; blue = mixotrophic) . The analysis displays a positive relationship between genome size and cell volume for heterotrophic and phototrophic chrysophyte strains. There is no positive relationship within mixotrophic chrysophyte strains

phototrophic strains were comparable to those reported for other taxonomic groups, whereas genome sizes of heterotrophic and mixotrophic genomes were among the smallest
Fig. 2 Genome size $[\mathrm{pg}]$ of investigated chrysophytes. Different colors represent the different nutritional modes present. Heterotrophic chrysophytes (dark red) tend to have smaller genome sizes, compared to phototrophic chrysophytes (light green), while mixotrophic chrysophytes (blue) show intermediate genome sizes. *Dinobryon sociale var. americana $\mathrm{cf}$. div. schauinslandii; $\mathrm{HF}=$ Heterotrophic flagellate

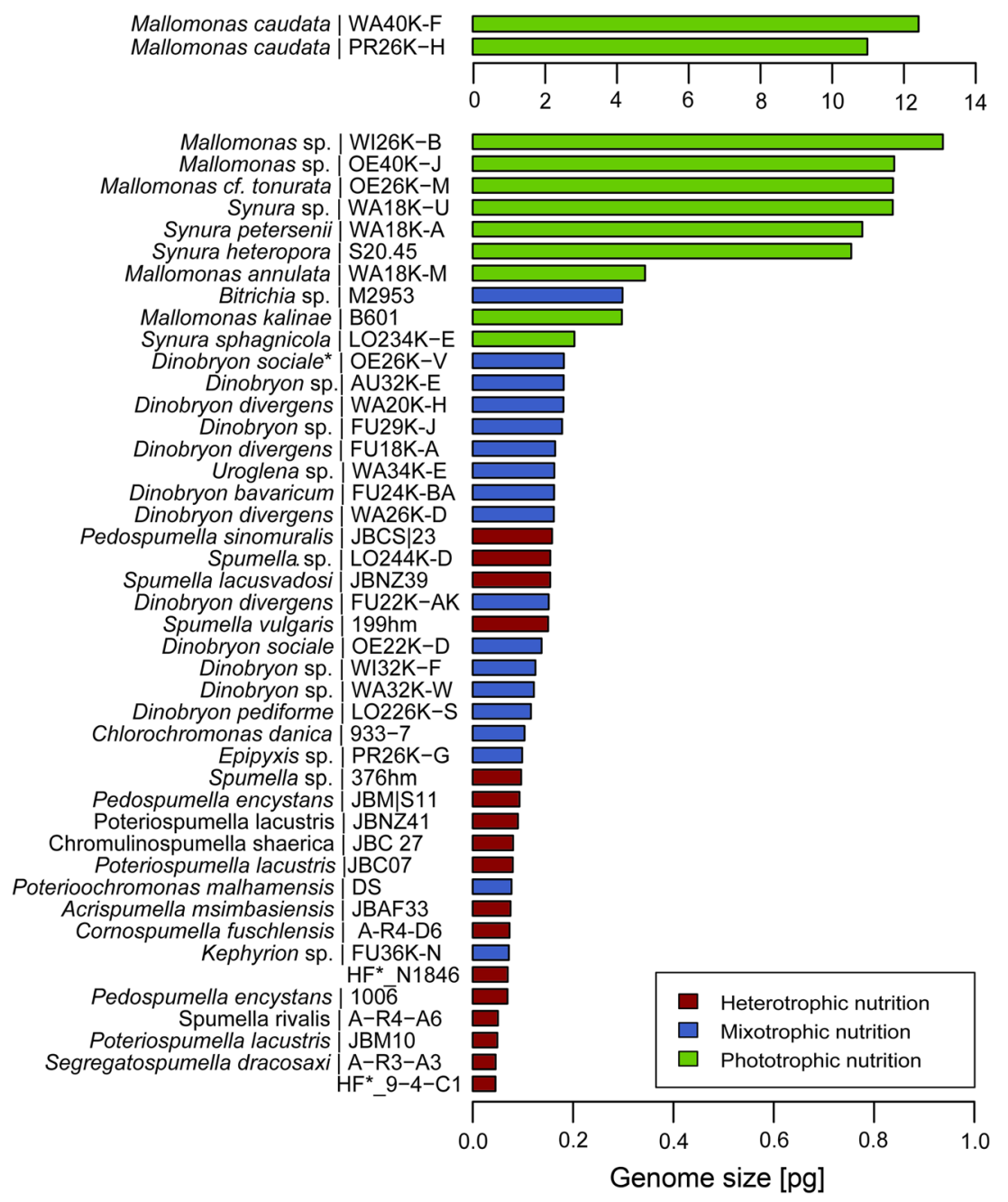




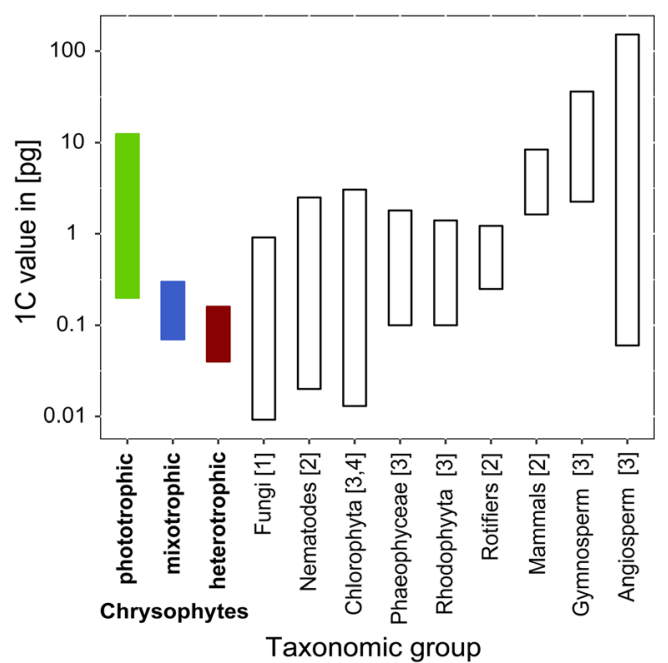

Fig. 4 Comparison of genome size within different taxonomic groups. Mixotrophic (blue) and heterotrophic (dark red) chrysophytes rank among the smallest eukaryotic genomes (values obtained from [1] Mohanta and Bae 2015; Egertová and Sochor 2017; [2] Gregory 2017; [3] Bennett 2012; [4] Courties et al. 1994)

genomes for compared eukaryotes (Fig. 4) (values obtained from Courties et al. 1994; Bennett 2012; Mohanta and Bae 2015; Egertová and Sochor 2017; Gregory 2017).

Consistent with studies on the Baccillariophyta (Conolly et al. 2008) and various plant species (Price et al. 1973; Cavalier-Smith 1985b; Dolezel et al. 1998), genome size increases with the cell volume, at least for the investigated phototrophic and heterotrophic chrysophyte strains (Fig. 3).

While generally in accordance with our initial hypotheses, results for mixotrophic organisms should be interpreted with care due to the bias introduced by the over-representation of the genus Dinobryon, among mixotrophic chrysophytes, which does not represent the whole diversity of genome sizes and cell volume in this trophic mode, since chrysophytes comprise numerous other mixotrophic genera (Beisser et al. 2017; Bock et al. 2017). In addition, the relative share of phototrophy and heterotrophy could affect genome size in mixotrophic taxa as well, since both nutritional strategies are used by different mixotrophic species to different extents. Furthermore, plastid size varies in these taxa, ranging from large plastids in genera like Dinobryon, with a photosynthetically active plastid, to genera like Poterioochromonas, in which the plastid is greatly reduced. In addition, one can detect great variation in cell size within the investigated mixotrophic chrysophytes: the predominant phototrophic strains of Dinobryon are larger and show a higher variability in cell volume than the predominantly heterotrophic strains, in particular Poterioochromonas. Therefore, we hypothesize that not only the genome size but also cell volume is associated with the degree of use of either phagocytosis or photosynthesis.

Assuming that cell volume is the dominant factor in determining genome sizes, all factors that influence cell size, including, e.g., grazing pressure, should affect genome size evolution as well (Conolly et al. 2008). Indeed, Bennett (1972) suggests that the genome has a function beyond the coding of genetic information: it also determines, e.g., the size of the nuclear envelope, which surrounds the genome and selects for a karyoplasmatic ratio that allows the optimal transfer of RNA (Cavalier-Smith 1985a).

However, since the investigated taxa affiliated with different trophic modes differed systematically in cell size, the effect of cell size and trophic mode could not clearly be separated.
Fig. 5 Model of evolution of genome size, cell volume, and nutritional mode of chrysophytes: nutrient limitations may have driven genome size reduction in the ancestors of mixotrophic (and heterotrophic) chrysophytes, as well as the evolution of phagotrophic mechanisms to attain additional nutrients. Cell size reduction is supposedly a more gradual process, coming into play in taxa which were already able to obtain nutrients by phagotrophy, which optimized food uptake by the optimization of the predator-prey size ratio. This may have triggered the evolution of obligate heterotrophs in many chrysophyte lineages independently

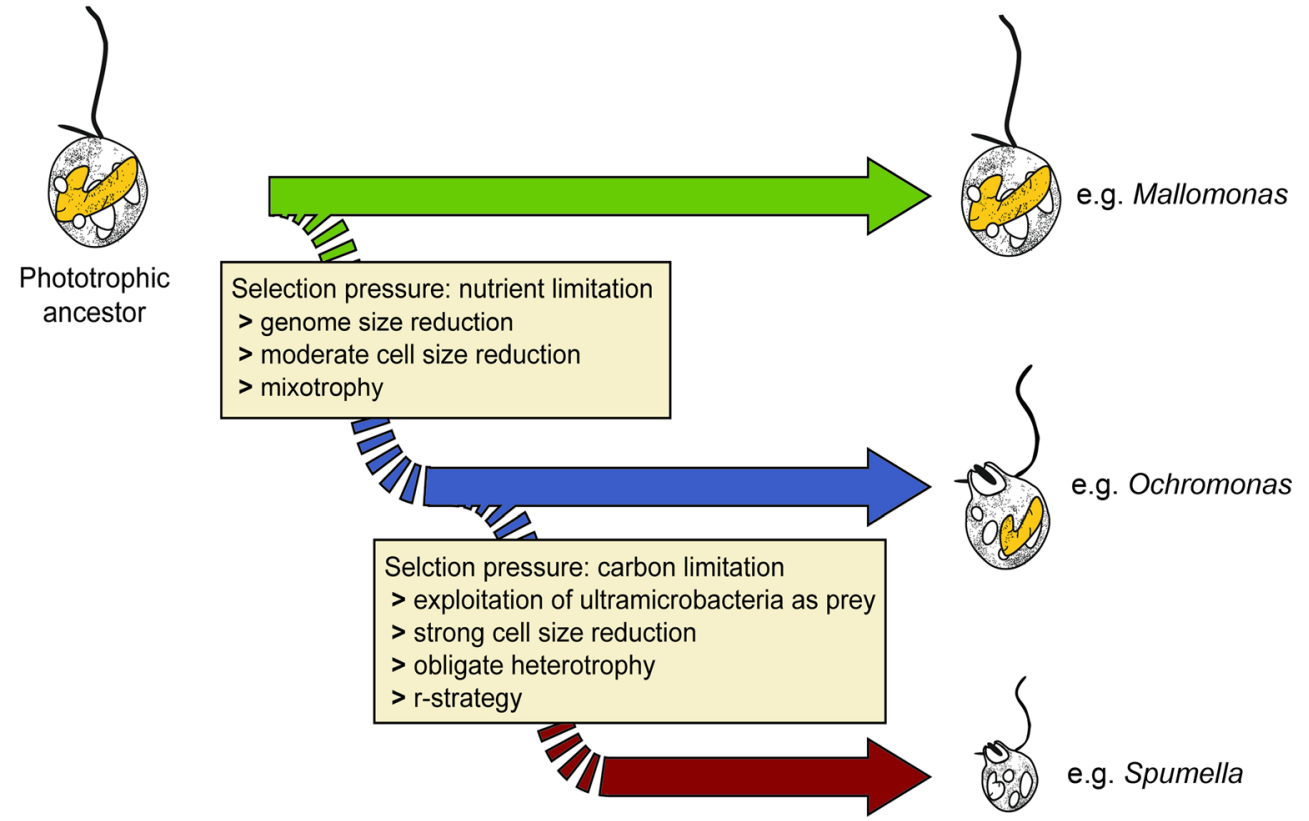


Systematic differences in cell volume and genome size between phototrophic, heterotrophic, and mixotrophic chrysophyte strains are likely to be associated with different life strategies. Phototrophic strains are associated with larger body size, a longer lifespan, and lower growth rates (Kapraun 2005; Cavalier-Smith 1980). In contrast, smaller genomes are associated with small body size and short generation time (Kapraun 2005; Cavalier-Smith 1980). Consistent with these observations, genome downsizing could result in increasing growth rates, because the time needed for mitosis and meiosis would be reduced (Hessen et al. 2010). This theory is supported by findings of Raven (1997), who discovered that pure phototrophs have lower maximum-specific growth rates than mixotrophs, which, in turn, have lower rates than pure heterotrophs (Raven 1997).

This trend is consistent for the investigated taxa and seems to be independent of the phylogenetic affiliation at least for mixotrophic and heterotrophic chrysophytes. As the Synurales are the only phototrophic taxon within Chrysophyceae, independent control groups within Chrysophyceae are missing with respect to phototrophs. Therefore, functional and phylogenetic effects cannot completely be resolved with respect to phototrophs.

Downsizing of genomes can occur in environments in which nitrogen $(\mathrm{N})$ and phosphate $(\mathrm{P})$ are limited. By contrast, genome size expansion is more likely in environments with high $\mathrm{N}$ and $\mathrm{P}$ supply, which suggests a possible role of $\mathrm{N}$ and $\mathrm{P}$ availability in the evolution of genomes (Sardans et al. 2012). The potential routes of nutrient uptake and nutrient availability in heterotrophic, mixotrophic, and phototrophic taxa could therefore systematically affect cell and genome size evolution. This is in accordance with our observation that the mode of nutrition appears to affect cell volume and genome size evolution.

As chrysophytes branch within the Ochrophyta, which comprise the phototrophic Stramenopiles, it is likely that mixotrophic and heterotrophic chrysophytes evolved from a phototrophic ancestor (Cavalier-Smith 1999; Aleoshin et al. 2016). A further evidence for this hypothesis is that the Synurophytes, which consist of only phototrophic representatives, branch relatively basal in a phylogenetic tree. However, the heterotrophic Paraphysomonadida also branch basal indicating that the loss of phototrophy occurred early in some branches of Chrysophyceae (Bock et al. 2017). As the basal branching pattern is not yet sufficiently resolved, we cannot fully exclude the possibility of early heterotrophic ancestors within Chrysophyceae even though such a scenario appears highly unlikely as it would require secondary "revival" of the plastid and plastid metabolism (Graupner et al. 2018).

However, if we assume a phototrophic ancestor of the chrysophytes to be limited in terms of nutrient availability, the acquisition of phagocytosis and invention of mixotrophy to evade such limitations would be a plausible scenario
(Burkholder et al. 2008) (Fig. 5). Especially the competition in allocation of P between DNA and RNA owing to P limitations could be a factor responsible for genome downsizing in evolutionary time (Hessen et al. 2008; Hessen et al. 2010). With invention of mixotrophy, the ratio of $\mathrm{C} / \mathrm{N}$ would rise, which is consistent with increased grazing activity (Sardans et al. 2012).

Abandonment of photosynthesis could also be due to energetical factors. In a purely phototrophic organism, the photosynthetic apparatus can account for $50 \%$ of the energetic costs of cell synthesis and comprises a huge amount of the cellular biomass (Raven 1997). For pure heterotrophs (with only remains of plastids), the corresponding fraction is usually below $10 \%$. In mixotrophic strains, some predominantly heterotrophic species have a strongly reduced photosynthetic apparatus, such as Poterioochromonas, whereas predominantly phototrophic taxa usually have a large photosynthetic apparatus. Therefore, the fraction of the energy and nutrients required by the photosynthetic apparatus may account for the difference between predominantly phototrophic or heterotrophic life strategies (Raven 1997).

Since mixotrophic organisms can obtain nutrients via phagotrophy, further selection towards downsizing of genomes due to a lack of nutrients is relaxed. Continuing, we would find genome sizes similar to those of heterotrophic chrysophytes if the process only depended on P limitations. Similarly, mixotrophic genome sizes would be comparable to those of phototrophic chrysophytes if the maintenance of the photosynthetic apparatus decided.

Therefore, the evolution towards smaller genomes seems to be driven by carbon (C) limitations (Fig. 5): Chrysophytes generally lack uptake mechanisms for carbon in the form of bicarbonate; they use carbon dioxide $\left(\mathrm{CO}_{2}\right)$, instead, which is primarily available in slightly acidic environments (Maberly et al. 2009). Predominantly, phototrophic chrysophytes are thus more restricted to acidic environments than predominantly heterotrophic ones. Heterotrophic chrysophytes are able to cover their requirements by preying upon bacteria. Due to this, a reduction of the cell size to optimize predator-prey interactions is reasonable. A small size allows for grazing on ultramicrobacteria (Castro et al. 2009) and therefore expands the spectrum of potential bacterial prey. This would be particularly beneficial in nutrient-limited environments (Nygaard and Tobiesen 1993), but if cell size decreases to a certain point, the necessity and ability of holding a functional plastid are questionable. As a consequence, purely heterotrophic nutrition modes can develop. Furthermore, optimized preying will result in the necessity to survive in environments with limited light, because bacterial abundances are higher in profundal regions resulting from decomposition processes.

By contrast, phototrophs are consistently large. The greater cell size of phototrophs allows for hosting a big functional plastid and may further be beneficial for swimming towards 
the sunlit upper water layer (Waite et al. 1997). However, for very large cells, the efficiency of light harvesting seems to decrease with increasing size (Geider et al. 1986). For diatoms, it was shown that large phototrophic cells have smaller relative chlorophyll concentrations (Agustí 1991) and that abundant chlorophyll interferes mutually, the so-called "package effect" (Finkel and Irwin 2000).

Surprisingly, for Mallomonas caudata, we could detect very high genome sizes and cell volumes. Higher cell volumes could serve as preying protection (Lampert and Sommer 2007). Generally, we can find diverse kinds of protection against preying, especially in Synurophytes, e.g., colony forming of Synura or cell size and spikes of different Mallomonas species. One mechanism leading to larger cell volumes is polyploidy. However, chrysophytes and their chromosomes are too small to determine the chromosome number by light microscopy. This restriction has also been observed in other species (Alberts et al. 2002; McIntyre 2012).

In general, a downsizing of genomes caused by nutrient limitations seems to be plausible in the case of chrysophytes because of the various nutritional modes observable. Although variations in nuclear-DNA content can arise via many other mechanisms as well, for instance by chromosome polymorphisms as well as polyploidy or duplications, there is still no generally accepted theory of what determines genome size (Cavalier-Smith 1982, 2005; Bennett and Leitch 2005). Particularly, polyploidy, which is common in plants (Soltis and Soltis 1999), could be another factor responsible for genome size variation and an important process in the genome evolution of chrysophytes (Conolly et al. 2008). Whole genome sequencing of selected chrysophyte strains is planned; this will presumably give us a greater insight into genome size evolution in chrysophytes.

Our findings suggest that

(i) the transition from phototrophy to mixotrophy, which occurred presumably early in chrysophyte evolution, is the force behind genome size reduction.

(ii) This may indicate that nutrient limitations on the ancestors of the mixotrophic (and heterotrophic) chrysophytes may have driven both genome size reduction as well as the evolution of phagotrophic mechanisms as a means of attaining additional nutrients in the presumably strongly nutrient-limited ancestors of these chrysophyte lineages.

(iii) Cell volume reduction is presumably a more gradual process which comes into play largely in taxa that were already able to obtain nutrients via phagotrophy as an adaptation to specific prey. Once the chrysophyte ancestors evolved the ability to take in food phagotrophically, optimizing food uptake via the optimization of the predator-prey size ratio presumably influenced cell size, e.g., by increasing the ability to prey upon ultramicrobacteria which consequently may have triggered the evolution of obligate heterotrophs in many chrysophyte lineages independently.
Acknowledgements We are grateful to Silvia Kempen and the working group Biodiversity and Evolution of Plants (Carl von Ossietzky University Oldenburg) who made it possible to measure genome sizes by flow cytometry and provided helpful commentaries to the results. We also would like to thank the German Research Foundation for financial support (projects BO 3245/17 and BO 3245/19).

\section{Compliance with ethical standards}

Conflict of interest The authors declare that they have no conflict of interest.

Open Access This article is distributed under the terms of the Creative Commons Attribution 4.0 International License (http:// creativecommons.org/licenses/by/4.0/), which permits unrestricted use, distribution, and reproduction in any medium, provided you give appropriate credit to the original author(s) and the source, provide a link to the Creative Commons license, and indicate if changes were made.

\section{References}

Agustí, S. (1991). Allometric scaling of light absorption and scattering by phytoplankton cells. Canadian Journal of Fisheries and Aquatic Sciences, 48(5), 763-767. https://doi.org/10.1139/f91-091.

Albach, D. C., \& Greilhuber, J. (2004). Genome size variation and evolution in Veronica. Annals of botany., 94(6), 897-911. https://doi. org/10.1093/aob/mch219.

Alberts, B., Johnson, A., Lewis, J., Raff, M., Roberts, K., Walter, P. (Hg.) (2002). Molecular biology of the cell. Chapter 4: the global structure of chromosomes. 4th edition. New York: Garland Science.

Aleoshin, V. V., Mylnikov, A. P., Mirzaeva, G. S., Mikhailov, K. V., \& Karpov, S. A. (2016). Heterokont Predator Develorapax marinus gen. et sp. nov. - A Model of the Ochrophyte Ancestor. Frontiers in microbiology, 7, 1194. https://doi.org/10.3389/fmicb.2016.01194.

Andersen, R. A., Graf, L., Malakhov, Y., \& Su Yoon, H. (2017). Rediscovery of the Ochromonas type species Ochromonas triangulata (Chrysophyceae) from its type locality (Lake Veysove, Donetsk region, Ukraine). Phycologia, 56(6), 591-604. https://doi. org/10.2216/17-15.1.

Beisser, D., Graupner, N., Bock, C., Wodniok, S., Grossmann, L., Vos, M., Sures, B., Rahmann, S., \& Boenigk, J. (2017). Comprehensive transcriptome analysis provides new insights into nutritional strategies and phylogenetic relationships of chrysophytes. PeerJ, 5, e2832. https://doi.org/10.7717/peerj.2832.

Bennett, M. D. (1972). Nuclear DNA content and minimum generation time in herbaceous plants. Proceedings of the Royal Society B: Biological Sciences, 181(1063), 109-135. https://doi.org/10.1098/ rspb.1972.0042.

Bennett, M. D. (2012). Plant DNA C-value Database (release 6.0). www. kew.org/cvalues.

Bennett, M. D., \& Leitch, I. J. (2005). Plant genome size research: A field in focus. Annals of botany, 95(1), 1-6. https://doi.org/10.1093/aob/ mci001.

Bock, C., Medinger, R., Jost, S., Psenner, R., Boenigk, J. (2014). Seasonal variation of planktonic chrysophytes with special focus on Dinobryon. Fottea, 179-190. https://doi.org/10.5507/fot.2014.014.

Bock, C., Chatzinotas, A., \& Boenigk, J. (2017). Genetic diversity in chrysophytes. Comparison of different gene markers. Fottea, 17(2), 209-221. https://doi.org/10.5507/fot.2017.005.

Bock, C., Wessel, C., Wu, W., Marks, S., Olefeld, J., Jensen, M., Boenigk, J. (submitted 2018). Cool and shady: Ecophysiological preferences of chrysophytes. Aquatic Microbial Ecology. 
Boenigk, J., Pfandl, K., \& Hansen, P. J. (2006). Exploring strategies for nanoflagellates living in a 'wet desert'. Aquatic Microbial Ecology, 44, 71-83. https://doi.org/10.3354/ame044071.

Boenigk, J., Pfandl, K., Stadler, P., \& Chatzinotas, A. (2005). High diversity of the 'Spumella-like' flagellates. An investigation based on the SSU rRNA gene sequences of isolates from habitats located in six different geographic regions. Environmental microbiology, 7(5), 685-697. https://doi.org/10.1111/j.1462-2920.2005.00743.x.

Burkholder, J. M., Glibert, P. M., \& Skelton, H. M. (2008). Mixotrophy, a major mode of nutrition for harmful algal species in eutrophic waters. Harmful Algae, 8(1), 77-93. https://doi.org/10.1016/j.hal.2008. 08.010 .

de Castro, F., Gaedke, U., \& Boenigk, J. (2009). Reverse evolution: Driving forces behind the loss of acquired photosynthetic traits. PLoS One, 4(12), e8465. https://doi.org/10.1371/journal.pone. 0008465

Cavalier-Smith, T. (1978). Nuclear volume control by nucleoskeletal DNA, selection for cell volume and cell growth rate, and the solution of the DNA C-value paradox. Journal of Cell Science, 1978(34), 247-278.

Cavalier-Smith, T. (1980). r- ad K-tactics in the evolution of protists developmental systems: cell and genome size, phenotype diversifying selection and cell cycle patterns. BioSystems (12), 43-59.

Cavalier-Smith, T. (1982). Skeletal DNA and the evolution of genome size. Annual review of biophysics and bioengineering, 11, 273-302. https://doi.org/10.1146/annurev.bb.11.060182.001421.

Cavalier-Smith, T. (1985a). The evolution of genome size. In T. CavalierSmith (Ed.), Eukaryote gene numbers, non-coding DNA and genome size. London, UK: Wiley.

Cavalier-Smith, T. (1985b). The evolution of genome size. In T. CavalierSmith (Ed.), Eukaryote gene numbers, non-coding DNA and genome size. London, UK: Wiley.

Cavalier-Smith, T. (2005). Economy, speed and size matter: Evolutionary forces driving nuclear genome miniaturization and expansion. Annals of botany, 95(1), 147-175. https://doi.org/10.1093/aob/ mci010.

Cavalier-Smith, T. (1999). Principles of protein and lipid targeting in secondary Symbiogenesis. Euglenoid, dinoflagellate, and Sporozoan plastid origins and the eukaryote family tree, $2 . J$ Eukaryotic Microbiology, 46(4), 347-366. https://doi.org/10.1111/ j.1550-7408.1999.tb04614.x.

Cienkowsky, L. (1870). Über Palmellaceen und einige Flagellaten. Archiv für Mikroskopische Anatomie, 6, 421-438.

Conolly, J. A., Oliver, M. J., Beaulieu, J. M., Knight, C. A., Tomanek, L., \& Moline, M. A. (2008). Correlated evolution of genome size and cell volume in diatoms (Bacillariophyceae). Journal of Phycology, 44, 124-131. https://doi.org/10.1111/j.1529-8817.2007.00452.x.

Courties, C., Vaquer, A., Troussellier, M., Lautier, J., Chrétiennot-Dinet, M. J., Neveux, J., et al. (1994). Smallest eukaryotic organism. Nature, 370(6487), 255. https://doi.org/10.1038/370255a0.

Dolezel, J., Bartos, J., Voglmayr, H., \& Greilhuber, J. (2003). Nuclear DNA content and genome size of trout and human. Cytometry Part $A$ : the journal of the International Society for Analytical Cytology, 51(2), 127-128; author reply 129. https://doi.org/10.1002/cyto.a. 10013.

Dolezel, J., Greilhuber, J., Lucretti, S., Meister, A., Lysák, M. A., Nardi, L., \& Obermayer, R. (1998). Plant genome size estimation by flow cytometry. Inter-laboratory comparison. Annals of botany, 82 (suppl_1), 17-26. https://doi.org/10.1093/oxfordjournals.aob. a010312.

Dolezel, J., Sgorbati, S., \& Lucretti, S. (1992). Comparison of three DNA fluorochromes for flow cytometric estimation of nuclear DNA content in plants. Physiol Plant, 85(4), 625-631. https://doi.org/10. 1034/j.1399-3054.1992.850410.x.

Dunn, O. J. (1964). Multiple comparisons using rank sums. Technometrics, (6). 241-252.
Egertová, Z., \& Sochor, M. (2017). The largest fungal genome discovered in Jafnea semitosta. Plant Syst Evol, 303(7), 981-986. https://doi. org/10.1007/s00606-017-1424-9.

Ehrenberg, C. G. (1834). Dritter Beitrag zur Erkenntniss grosser Organisation in der Richtung des kleinsten Raumes. Abhandlungen der Königlichen Akademie der Wissenschaften zu Berlin, 1833, 145-336.

Ehrenberg, C. G. (1838). Die Infusionsthierchen als vollkommene Organismen: Ein Blick in das tiefere organische Leben der Natur (pp. i-xviii, [1-4], 1-547, [1]. Leipzig: Verlag von Leopold Voss.

Findenig, B. M., Chatzinotas, A., \& Boenigk, J. (2010). Taxonomic and ecological characterization of stomatocysts ofspumella-like flagellates (Chrysophyceae). Journal of Phycology, 46(5), 868-881. https://doi.org/10.1111/j.1529-8817.2010.00892.x.

Finkel, Z. V., \& Irwin, A. J. (2000). Modeling size-dependent photosynthesis: Light absorption and the allometric rule. Journal of theoretical biology, 204(3), 361-369. https://doi.org/10.1006/jtbi.2000. 2020.

Galbraith, D. W., Harkins, K. R., Maddox, J. M., Ayres, N. M., Sharma, D. P., Firoozabady, E. (1983) Rapid flow cytometric analysis of the cell cycle in intact plant tissues. Science (220), 1049-1051. https:// doi.org/10.1126/science.220.4601.1049.

Geider, R. J., Platt, T., Raven, J. A. (1986). Size dependence of growth and photosynthesis in diatoms a synthesis. Marine Ecology Programme Series (30), 93-104.

Gelman, A., Goodrich, B., Gabry, J., Ali, I. (2017), R-squared for Bayesian regression models. Unpublished via http://www.stat. columbia.edu/ gelman/research/unpublished/.

Graupner, N., Jensen, M., Bock, C., Marks, S., Rahmann, S., Beisser, D., Boenigk, J. (2018). Evolution of heterotrophy in chrysophytes as reflected by comparative transcriptomics. FEMS microbiology ecology, 94. https://doi.org/10.1093/femsec/fiy039

Gregory, T. R. (2017). Animal Genome Size Database. www.genomesize. com.

Greilhuber, J., Dolezel, J., Lysák, M. A., \& Bennett, M. D. (2005). The origin, evolution and proposed stabilization of the terms 'genome size' and 'C-value' to describe nuclear DNA contents. Annals of botany, 95(1), 255-260. https://doi.org/10.1093/aob/mci019.

Grossmann, L., Bock, C., Schweikert, M., \& Boenigk, J. (2016). Small but Manifold - Hidden Diversity in "Spumella-like Flagellates". The Journal of eukaryotic microbiology, 63(4), 419-439. https://doi.org/ 10.1111/jeu.12287.

Guillard, R. R. L., \& Lorenzen, C. J. (1972). Yellow-geen algae with Chloropyllide C. Journal of Phycology, 8(1), 10-14. https://doi. org/10.1111/j.1529-8817.1972.tb03995.x.

Gupta, A., LaBar, T., Miyagi, M., \& Adami, C. (2016). Evolution of genome size in asexual digital organisms. Scientific reports, 6 , 25786. https://doi.org/10.1038/srep25786.

Hahn, M. W., Lunsdorf, H., Wu, Q., Schauer, M., Hofle, M. G., Boenigk, J., \& Stadler, P. (2003). Isolation of novel Ultramicrobacteria classified as Actinobacteria from five freshwater habitats in Europe and Asia. Applied and Environmental Microbiology, 69(3), 1442-1451. https://doi.org/10.1128/AEM.69.3.1442-1451.2003.

Harris, K. (1967). Variability in Mallomonas. Journal of General Microbiology, 46, 185-191.

Hessen, D. O., Jeyasingh, P. D., Neiman, M., \& Weider, L. J. (2010). Genome streamlining and the elemental costs of growth. Trends in ecology \& evolution, 25(2), 75-80. https://doi.org/10.1016/j.tree. 2009.08.004

Hessen, D. O., Ventura, M., \& Elser, J. J. (2008). Do phosphorus requirements for RNA limit genome size in crustacean zooplankton? Genome, 51(9), 685-691. https://doi.org/10.1139/G08-053.

Imhof, O. E. (1887). Studien über die Fauna hochalpiner Seen, insbesondere des Cantons Graubünden. Jahresbericht der Naturforschenden Gesellschaft Graubündens, 30, 45-164. 
Imhof, O. E. (1890). Das Flagellatengenus Dinobryon. Zoologischer Anzeiger, 13, 483-488.

Iwanoff, L. A. (1899). Beitrag zur Kenntnis der Morphologie und Systematik der Chrysomonadinen. Bulletin de l'Académie Impériale des Sciences de Saint Pétersbourg, 5, 247-262.

Kapraun, D. F. (2005). Nuclear DNA content estimates in multicellular green, red and brown algae: Phylogenetic considerations. Annals of botany, 95(1), 7-44. https://doi.org/10.1093/aob/mci002.

Koester, J. A., Brawley, S. H., Karp-Boss, L., \& Mann, D. G. (2007). Sexual reproduction in the marine centric diatom Ditylum brightwellii (Bacillariophyta). European Journal of Phycology, 42(4), 351-366. https://doi.org/10.1080/09670260701562100.

Korshikov, A. A. (1929). Studies on the Chrysomonads I. Archiv für Protistenkunde, 67, 253-290.

Kremp, A. (2013). Diversity of dinoflagellate life cycles: Facets and implications of complex strategies. Biological and Geological Perspectives of Dinoflagellates, S. 189-198. https://doi.org/10. 1144/TMS5.18.

Kristiansen, J., Škaloud, P. (2017). Chrysophyta. In Handbook of the Protists, Chrysophyta. https://doi.org/10.1007/978-3-319-28149-0_ 43

Kruskal, W. H., Wallis, W. A. (1952). Use of ranks in one-criterion variance analysis. Journal of the American Statistical Association, 47, 583-621.

Lampert, W., \& Sommer, U. (2007). Limnoecology: The ecology of lakes and streams (2nd ed.). Oxford: Oxford Univ. Press.

Maberly, S. C., Ball, L. A., Raven, J. A., \& Sultemeyer, D. (2009). Inorganic carbon Aquisition by Chrysophytes. Journal of Phycology, 45(5), 1052-1061. https://doi.org/10.1111/j.1529-8817. 2009.00734.x.

McIntyre, P. J. (2012). Cytogeography and genome size variation in the Claytonia perfoliata (Portulacaceae) polyploid complex. Annals of botany, 110(6), 1195-1203. https://doi.org/10.1093/aob/mcs187.

Meudt, H. M., Rojas-Andrés, B. M., Prebble, J. M., Low, E., GarnockJones, P. J., \& Albach, D. C. (2015). Is genome downsizing associated with diversification in polyploid lineages of Veronica? Botanical Journal of the Linnean Society, 178(2), 243-266. https:// doi.org/10.1111/boj.12276.

Mohanta, T. K., \& Bae, H. (2015). The diversity of fungal genome. Biological procedures online, 17, 8. https://doi.org/10.1186/ s12575-015-0020-z.

Nygaard, K., Tobiesen, A. (1993). Bacterivory in algae a survival strategy during nutrient limitation. Limnol Oceanog (38), 273-279.

Pascher, A. (1911). Über Nannoplanktonten des Süsswassers. Berichte der deutsche botanischen Gesellschaft, 29, 523-533.

Perty, M. (1852). Zur Kenntniss kleinster Lebensformen: nach Bau, Funktionen, Systematik, mit Specialverzeichniss der in der Schweiz beobachteten. Verlag von Jent \& Reinert, 1-228.
Péterfi, L. S. (1969). The fine structure of Poterioochromonas malhamensis (Pringsheim) comb. nov. with special reference to the lorica. Nova Hedwigia, 17, 93-103.

Price, H. J., Sparrow, A. G., \& Naumann, A. F. (1973). Correlations between nuclear volume, cell volume, and DNA content in meristematic cells of herbaceous angiosperms. Experentia, 29, 1028-1029.

Raven, J. A. (1997). Phagotrophy in phototrophs. Limnol. Oceanogr., 42(1), 198-205. https://doi.org/10.4319/lo.1997.42.1.0198.

Rezácova, M. (2006). Mallomonas kalinae (Synurophyceae), a new species of alga from northern Bohemia, Czech Republic. Preslia, 78, 353-358.

Sandgren, C. D. (1991). Chrysophyte reproduction an resting cysts: A paleolimnologist's primer. Journal of Paleolimnology, 5, 1-9.

Sardans, J., Rivas-Ubach, A., \& Peñuelas, J. (2012). The elemental stoichiometry of aquatic and terrestrial ecosystems and its relationships with organismic lifestyle and ecosystem structure and function. A review and perspectives. Biogeochemistry, 111(1-3), 1-39. https:// doi.org/10.1007/s10533-011-9640-9.

Shapiro, S. S., Wilk, M. B. (1965). An analysis of variance test for normality (complete samples). Biometrica (52), 591-611. https://doi. org/10.2307/2333709.

Šidák, Z. (1967). Rectangular confidence regions for the means of multivariate normal distributions. Journal of the American Statistical Association (62), 626-633.

Škaloud, P., Škaloudová, M., Procházková, A., \& Němcová, Y. (2014). Morphological delineation and distribution patterns of four newly described species within the Synura petersenii species complex (Chrysophyceae, Stramenopiles). European Journal of Phycology, 49(2), 213-229. https://doi.org/10.1080/09670262.2014.905710.

Soltis, D. E., Soltis, P. S. (1999). Polyploidy: recurrent formation and genome evolution. Trends Ecology and Evolution, 14 348-352.

Steinecke, F. (1916). Die Algen des Zehlaubruches in systematischer und biologischer Hinsicht. Schriften der koniglichen physikalischokonomischen Gesellschaft zu Konigsberg, 56, 1-138.

Teiling, E. (1912). Schwedische Planktonalgen. I. Phytoplankton aus dem Råstasjön bei Stockholm. Svensk Botanisk Tidskrift, 6(2), 267-281.

Temsch, E. M., Greilhuber, J., \& Krisai, R. (2010). Genome size in liverworts. Preslia, 82, 63-80.

Waite, A., Fischer, A., Thompson, P. A., Harrison, P. J. (1997). Sinking rate versus cell volume relationships illuminate sinking rate control mechanisms in marine diatoms. MEPS (157), 97-108. https://doi. org/10.3354/meps157097.

Woloszynska, J. (1914). Zapiski algologiczne/Algologische Notizen. Sprawozdania z Posiedzen Towarzystwa Naukowego Warszawskiego. Wydzial II, 7, 22-26. 